\title{
Bacterial Vaginosis Biofilms: Challenges to Current Therapies and Emerging Solutions
}

\author{
Daniela Machado ${ }^{1}$, Joana Castro ${ }^{1,2}$, Ana Palmeira-de-Oliveira ${ }^{3,4}$, \\ José Martinez-de-Oliveira ${ }^{3,5}$ and Nuno Cerca ${ }^{1 *}$
}

' Laboratory of Research in Biofilms Rosário Oliveira, Centre of Biological Engineering, University of Minho, Braga, Portugal, ${ }^{2}$ Instituto de Ciências Biomédicas Abel Salazar, Universidade do Porto, Porto, Portugal, ${ }^{3}$ Health Sciences Research Center, Faculty of Health Sciences, University of Beira Interior, Covilhã, Portugal, ${ }^{4}$ Labfit, Health Products Research and Development Lda, Covilhã, Portugal, ${ }^{5}$ Child and Woman's Health Department, Centro Hospitalar Cova da Beira, Covilhã, Portugal

\section{OPEN ACCESS}

Edited by:

Johnan A. R. Kaleeba, Uniformed Services University of the Health Sciences, USA

Reviewed by: Don A Baldwin,

Signal Biology, Inc., USA

Elisabeth Margaretha Bik,

Stanford University School of Medicine, USA

${ }^{*}$ Correspondence: Nuno Cerca nunocerca@ceb.uminho.pt

Specialty section: This article was submitted to Infectious Diseases,

a section of the journal

Frontiers in Microbiology

Received: 22 October 2015 Accepted: 18 December 2015

Published: 20 January 2016

Citation:

Machado D, Castro J,

Palmeira-de-Oliveira A Martinez-de-Oliveira $J$ and Cerca $N$ (2016) Bacterial Vaginosis Biofilms: Challenges to Current Therapies and Emerging Solutions.

Front. Microbiol. 6:1528. doi: 10.3389/fmicb.2015.01528
Bacterial vaginosis (BV) is the most common genital tract infection in women during their reproductive years and it has been associated with serious health complications, such as preterm delivery and acquisition or transmission of several sexually transmitted agents. BV is characterized by a reduction of beneficial lactobacilli and a significant increase in number of anaerobic bacteria, including Gardnerella vaginalis, Atopobium vaginae, Mobiluncus spp., Bacteroides spp. and Prevotella spp.. Being polymicrobial in nature, BV etiology remains unclear. However, it is certain that BV involves the presence of a thick vaginal multi-species biofilm, where G. vaginalis is the predominant species. Similar to what happens in many other biofilm-related infections, standard antibiotics, like metronidazole, are unable to fully eradicate the vaginal biofilm, which can explain the high recurrence rates of BV. Furthermore, antibiotic therapy can also cause a negative impact on the healthy vaginal microflora. These issues sparked the interest in developing alternative therapeutic strategies. This review provides a quick synopsis of the currently approved and available antibiotics for BV treatment while presenting an overview of novel strategies that are being explored for the treatment of this disorder, with special focus on natural compounds that are able to overcome biofilm-associated antibiotic resistance.

Keywords: bacterial vaginosis, biofilms, Gardnerella vaginalis, antibiotics, emerging therapies

\section{INTRODUCTION}

The healthy vaginal microflora has been described as being constituted mainly by Gram-positive bacilli of the genus Lactobacillus, being L. crispatus, L. iners, L. gasseri, and L. jensenii the most common species (Ravel et al., 2011). However, other non-beneficial microbial species, including Gardnerella vaginalis, Enterococcus spp., and Prevotella spp., can be present in small numbers, not sufficient to cause disease (Marrazzo et al., 2002). Importantly, lactobacilli play a pivotal role in maintaining the female genital tract health while preventing genitourinary infections (Borges et al., 2014).

Among genital infections, bacterial vaginosis (BV) is the leading vaginal disorder in women of childbearing age, contributing to more than $60 \%$ of all vulvovaginal infections (Sobel, 2000). BV, as

Abbreviations: BV, Bacterial Vaginosis; CDC, Centers for Disease Control and Prevention; LAE, Lauramide Arginine Ethyl Ester. 
a whole, has been associated with serious health problems, including pre-term birth (Leitich et al., 2003), spontaneous abortion (Guerra et al., 2006), pelvic inflammatory disease (Rothman et al., 2003), endometritis (Jacobsson et al., 2002) and acquisition and transmission of several sexually transmitted agents (Gallo et al., 2012). Clinically, a profuse vaginal discharge and a rotten fish vaginal odor are characteristic symptoms, although some women with BV remain asymptomatic (Koumans et al., 2007). Microbiologically, this condition is characterized by a dramatic shift of vaginal microflora which involves the loss of beneficial bacteria (lactobacilli) and a simultaneous proliferation of anaerobic bacteria including G. vaginalis, Atopobium vaginae, Mobiluncus spp., Bacteroides spp., and Prevotella spp. (Verhelst et al., 2004). Its high prevalence and the associated complications make BV an important public health issue. However, due to the great diversity and complexity of microorganisms involved, the BV etiopathogenesis is not yet fully understood and is still a matter of controversy (Schwebke et al., 2014).

Back in 1955, Gardner and Dukes proposed that G. vaginalis was the sole etiological agent of BV (Gardner and Dukes, 1955). However, their findings were disputed when some years later $G$. vaginalis was found in approximately $40 \%$ of healthy women. In addition, other anaerobic bacteria were positively associated with BV and this lead researchers to conclude that BV was a polymicrobial infection (Sobel, 2000). However, a major conceptual problem with this later hypothesis is its inconsistency with epidemiological data, which suggests that BV is a sexual transmitted disease and therefore, most likely to be caused by a single agent (Josey and Schwebke, 2008). Currently, is consensual that BV involves the presence of a dense, structured and polymicrobial biofilm, primarily constituted by $G$. vaginalis clusters, strongly adhered to the vaginal epithelium (Swidsinski et al., 2005). Biofilms are communities of microorganisms attached to a surface and encased in a polymeric matrix of polysaccharides, proteins and nucleic acids (Høiby et al., 2011). Due to the fact that bacteria within biofilms are not effectively eliminated by the immune system (Cerca et al., 2006; Xie et al., 2012) or fully destroyed by antibiotics (Cerca et al., 2005; Tobudic et al., 2012), biofilm-related infections tend to persist and so, not surprisingly, BV tends to have a high rate of relapse and recurrence (Bradshaw et al., 2006). So, the current paradigm is that the establishment of a $G$. vaginalis biofilm is a required event for initiation and progression of BV (Machado and Cerca, 2015). In fact, in vitro studies demonstrated that $G$. vaginalis biofilm displays a high resistance to the protective mechanisms of normal vaginal microflora, including hydrogen peroxide, and lactic acid produced by lactobacilli (Patterson et al., 2007), as well as an increased tolerance to antibiotics (Swidsinski et al., 2008). Therefore, vaginal biofilms play a key role not only in BV pathogenesis, but also in its treatment failure and recurrence. Thus, the purpose of this review is to present currently approved and available therapeutic strategies for BV, as well as to discuss the emerging therapies that are being explored for BV treatment, attributing more emphasis to novel therapeutics targeting vaginal biofilms.

\section{CURRENT BV ANTIBIOTIC THERAPEUTIC OPTIONS}

Despite the most recent discoveries related to the etiology of $\mathrm{BV}$, current treatment is still directed toward alleviation of symptoms through reduction of $\mathrm{BV}$-associated bacteria overgrowth and restoration of normal vaginal flora (Pirotta et al., 2009). The Centers for Disease Control and Prevention (CDC) recommends that all symptomatic women should be treated, since it recognizes several benefits of therapy, including the relief of the symptoms and signs of infection (Centers for Disease Control and Prevention, 2015) and the reduction in the risk of acquiring sexually transmitted diseases (Brotman et al., 2010). Conventionally, BV is treated with metronidazole, clindamycin or tinidazole (Centers for Disease Control and Prevention, 2015).

Presently, metronidazole is considered to be the drug of choice for BV treatment (Centers for Disease Control and Prevention, 2015). It is a first generation nitroimidazole, which was initially indicated for the management of trichomoniasis (Moffett and Mcgill, 1960) but was then shown to be effective against anaerobic microorganisms (Tally et al., 1975). However, metronidazole therapy is associated with several side effects such as nausea, vomiting and gastrointestinal complaints (Schwebke and Desmond, 2011; Abdali et al., 2015; Chavoustie et al., 2015; Schwebke et al., 2015). Clindamycin is also an antimicrobial agent for BV treatment (Centers for Disease Control and Prevention, 2015), with similar efficacy as metronidazole (Paavonen et al., 2000; Beigi et al., 2004). It is a lincosamide that is available in various pharmaceutical formulations including vaginal dosage forms and oral (systemic) pills(Menard, 2011). However, when applied topically, clindamycin might weaken latex products such as condoms (Rosen and Rosen, 1999) and may even cause pseudomembranous colitis (Trexler et al., 1997). Tinidazole was the most recently approved antimicrobial agent for BV treatment, by the Food and Drug Administration (Dickey et al., 2009) and it is considered an alternative antimicrobial agent for BV treatment particularly whenever metronidazole and clindamycin are unavailable or not tolerated (Centers for Disease Control and Prevention, 2015). Being a second generation nitroimidazole with a longer half-life than metronidazole (Wood and Monro, 1975 ) it requires lower dosages, to be taken less frequently than metronidazole (Dickey et al., 2009). Other antibiotics like ornidazole (Thulkar et al., 2012), secnidazole (Núñez and Gómez, 2005; Bohbot et al., 2010; Thulkar et al., 2012) and azithromycin (Nikolov et al., 2008) have been tested as alternatives to treat BV, however these antibiotics are not currently approved by the Food and Drug Administration and have not shown to increase BV cure rates.

Despite the high cure rates achieved in some studies, very high $\mathrm{BV}$ recurrence rates and some relevant treatment side effects have been reported. A list of the most recent studies (2010-2015) is presented in Table 1.

The low efficacy of antibiotics in preventing recurrences is thought to be due to their inability to fully eradicate BV vaginal biofilms-associated bacteria. In fact, Swidsinski and colleagues investigated the influence of oral metronidazole therapy on $G$. vaginalis biofilms and reported that biofilms were only 


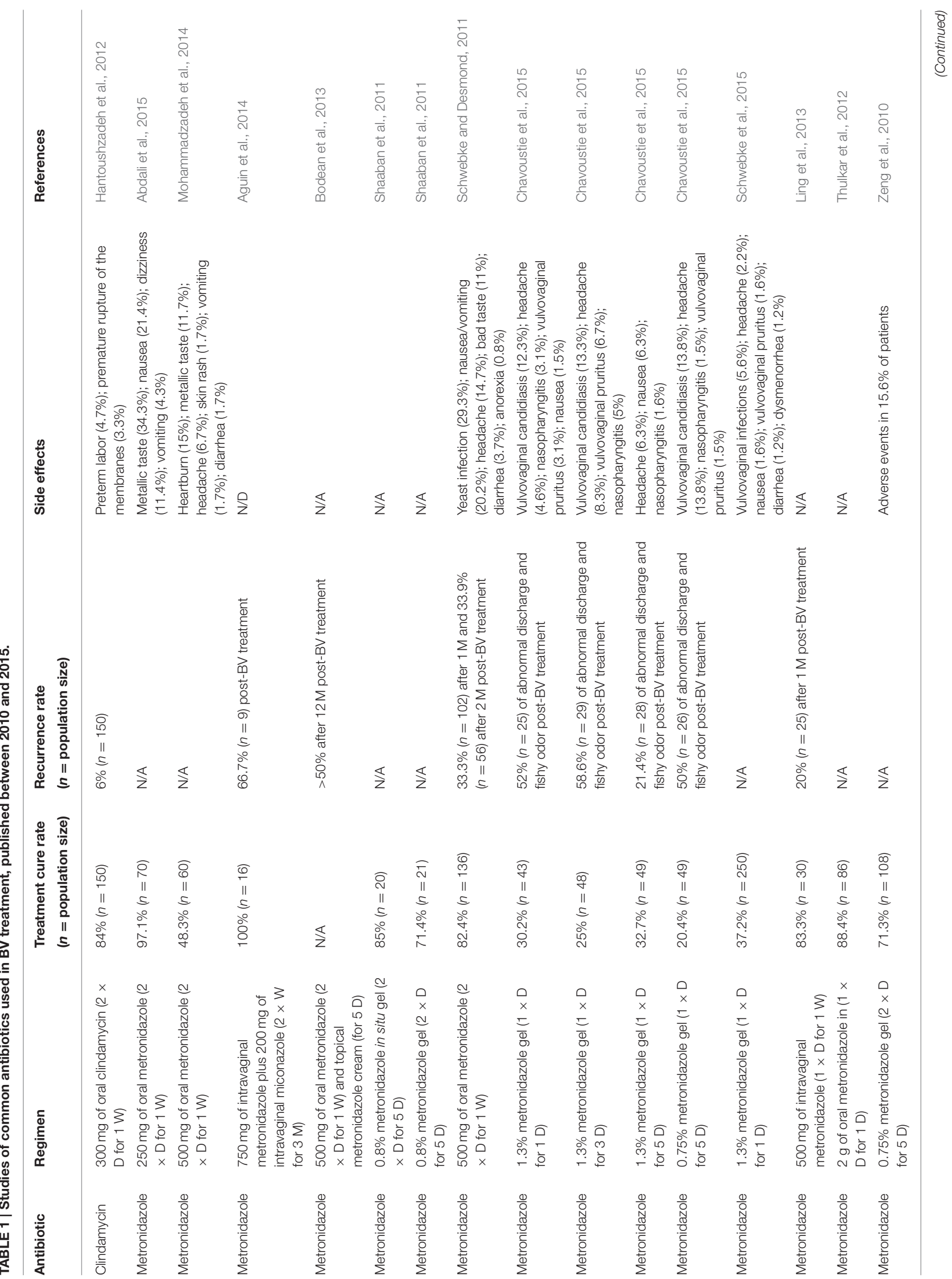




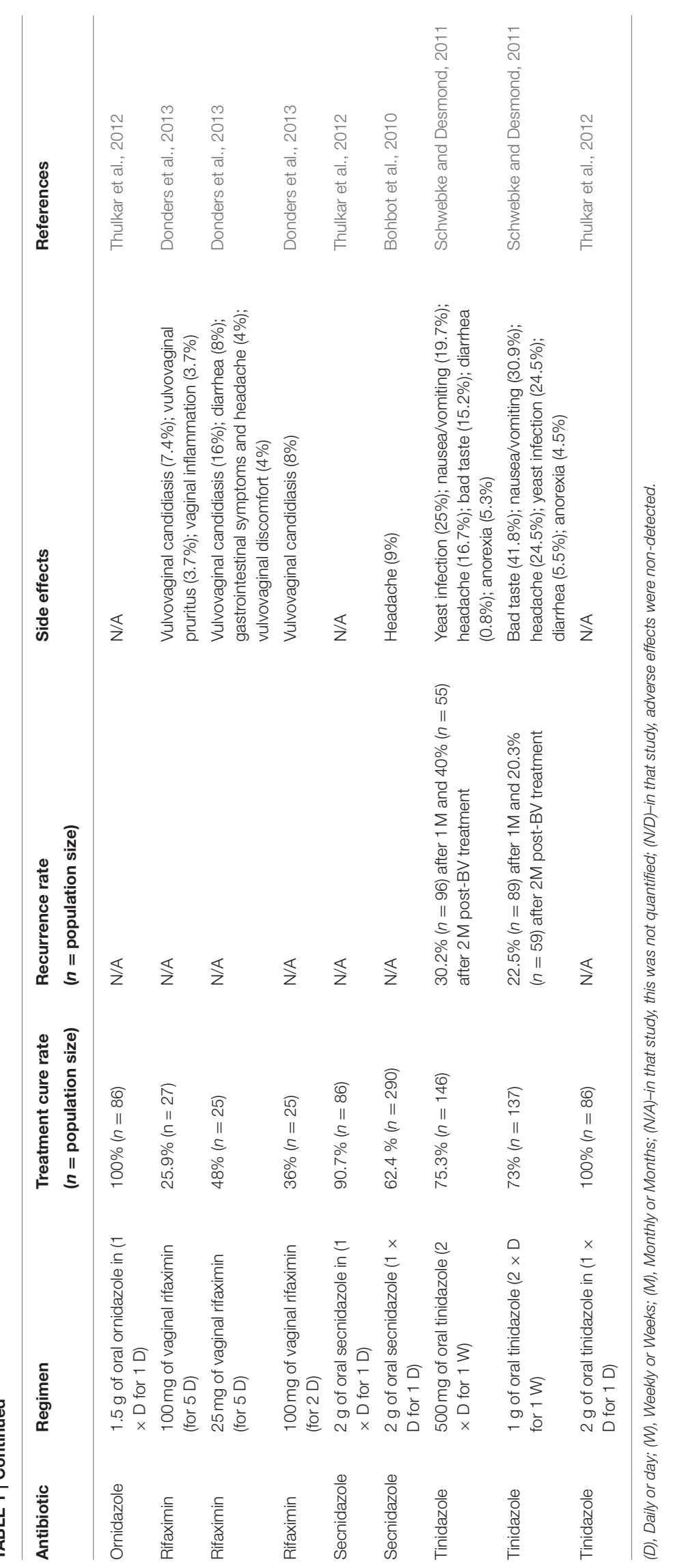


temporarily suppressed, and that in most cases rapidly regained activity following treatment cessation (Swidsinski et al., 2008). Later, Alves and colleagues determined the in vitro susceptibility of $30 \mathrm{BV}$-associated biofilm forming bacteria to metronidazole, tinidazole, and clindamycin and showed that all tested bacteria tested were resistant to metronidazole and tinidazole and $67 \%$ to clindamycin (Alves et al., 2014). In this sense, novel antimicrobials agents, with the ability to selectively target vaginal pathogens and their biofilms, are urgently required.

\section{EMERGING THERAPEUTIC ALTERNATIVES AGAINST BV}

The increasing evidence that BV is a biofilm-mediated infection sparked the interest of the scientific community in exploring agents aimed to disrupting biofilms. Thus, in recent years, studies of anti-BV agents started to include biofilm disruptor candidates, such as DNases, retrocyclins, probiotics, antiseptics, natural antimicrobials, and plant-derived compounds (see Table 2).

\section{Antiseptics}

During several decades, antiseptics have been applied in the management of vaginal infections (Ratzan, 1969; Ison et al., 1987). They have an antibacterial activity against a broad spectrum of bacteria, acting by nonspecifically disrupting their cell membrane (Lachapelle et al., 2013). A great panoply of antiseptics have been used to treat BV, including dequalinium chloride (Petersen et al., 2002), povidone iodide (Wewalka et al., 2002), hydrogen peroxide (Cardone et al., 2003), polyhexamethylene biguanide (Gerli et al., 2003), chlorhexidine (Molteni et al., 2004), octenidine hydrochloride/phenoxyethanol (Novakov Mikic and Budakov, 2010), nifuratel (Togni et al., 2011), and benzydamine hydrochloride (Boselli et al., 2012). However, a recent systematic review verified that most studies addressing the use of antiseptics for BV treatment are somehow methodologically weak since follow-up studies were very limited and their safety and excipients composition was poorly investigated (Verstraelen et al., 2012). Nevertheless, the potential of antiseptics against BV biofilms was recently highlighted when Swidsinski and colleagues reported high initial cure rates when using octenidine. However, the efficacy of prolonged and repeated treatment was lower than expected and bacterial resistance emerged in a considerable subset of women (Swidsinski et al., 2015).

\section{Probiotics and Prebiotics}

An alternative approach to deal with BV is by modulating the vaginal microbiota, for example, by using probiotics. Probiotics are live microorganisms which confer a health benefit to the host, when administered in suitable amounts (Food Agriculture Organization of the United Nations World Health Organization, 2001). In the human vagina, certain Lactobacillus strains can act as probiotics, preventing the growth of BV-associated bacteria through two main mechanisms: the inhibition of pathogens adhesion to vaginal epithelium (Machado et al., 2013); and the production of antimicrobial compounds like hydrogen peroxide (Mastromarino et al., 2002), lactic acid (Boskey et al., 2001) and bacteriocins (Aroutcheva et al., 2001b). Diverse pharmaceutical formulations containing probiotic lactobacilli strains have reduced BV symptoms, improved the vaginal microflora profile, being usually well-tolerated (Rossi et al., 2010; Hantoushzadeh et al., 2012; Facchinetti et al., 2013; Vujic et al., 2013; Vicariotto et al., 2014). In contrast, despite their therapeutic potential, some clinical trials have not detected a significant improvement in BV management (Falagas et al., 2007). Alternatively, probiotics have been proposed as adjuvants to antibiotic therapy. Several combinations of metronidazole, clindamycin or tinidazole with lactobacilli probiotic preparations have displayed promising results in BV treatment since they have been associated with high cure rates, low recurrence or quick re-establishment of an healthy vaginal microflora (Marcone et al., 2010; Bodean et al., 2013; Recine et al., 2016). Probiotics have also been used in an attempt to specifically deal with BV biofilms. Remarkably, in 2007, Saunders and colleagues showed that L. reuteri RC-14 was able to disrupt in vitro $G$. vaginalis biofilms (Saunders et al., 2007). Later, McMillan and colleagues demonstrated that probiotic $L$. reuteri $\mathrm{RC}-14$ and $L$. rhamnosus GR-1 were able to incorporate themselves into BVbiofilm, composed by G. vaginalis and A. vaginae, causing both the disruption of the biofilm structure and bacterial cell death (McMillan et al., 2011). These findings provide some evidence of how lactobacilli probiotics might interfere with an abnormal vaginal microflora, reinforcing the hypothesis that probiotics could eradicate vaginal pathogenic biofilms and restore the normal microflora in in vivo situations.

It has also been proposed that prebiotics, nutritional substances that stimulate the growth of probiotics, could be used as alternative to treat BV (Roberfroid, 2007). Interestingly, Rousseau and colleagues demonstrated that prebiotic preparations containing oligosaccharides were able to promote the growth of beneficial lactobacilli strains but not of the pathogenic microorganisms often found in urogenital infections including G. vaginalis (Rousseau et al., 2005). Later, Zeng and colleagues compared the efficacy of a prebiotic gel containing sucrose with $0.75 \%$ metronidazole vaginal gel to treat BV (Zeng et al., 2010). In that study, the prebiotic gel displayed a similar therapeutic cure rate to metronidazole, having a major advantage of quicker restoration of the normal vaginal microflora. Recently, Coste and colleagues evaluated the efficacy and safety of another prebiotic gel, applied as adjuvant therapy, in women treated for $\mathrm{BV}$ and showed an improved recovery of the normal vaginal flora, reducing the risk of recurrences (Coste et al., 2012).

\section{Plant-Derived Compounds}

The use of plant-derived compounds in the treatment of genital infections is another therapy on the rise (Palmeira-de-Oliveira et al., 2013). One of the earliest reports on this topic dates back from 1991, when Blackwell described the first therapeutic success of using plants extracts to treat BV (Blackwell, 1991). Subsequently, several clinical trials have demonstrated that the use of plant-derived compounds promoted the reduction of BV symptoms and are associated with high cure rates and tolerability, including a polyherbal vaginal pessary (Patel et al., 2008), vaginal 

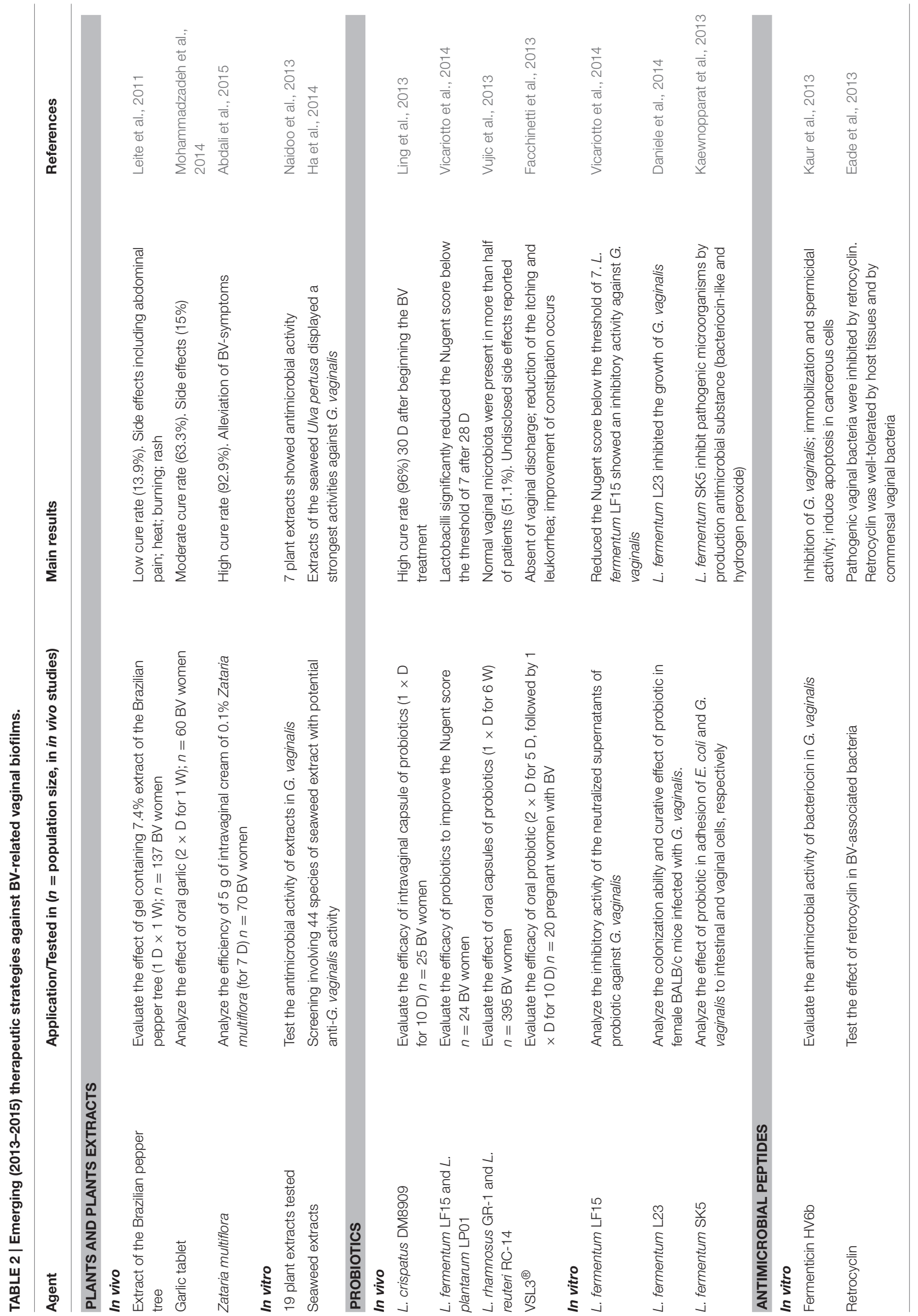

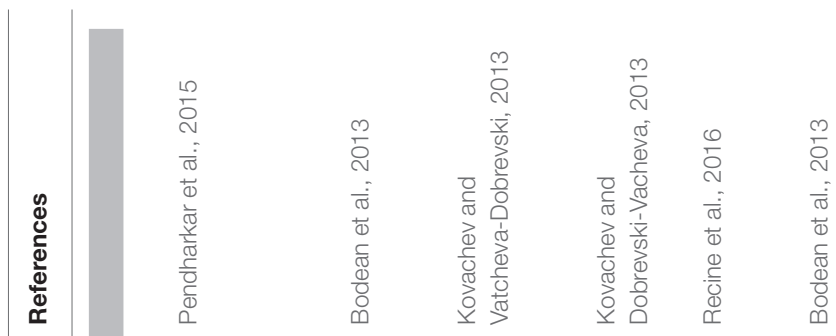

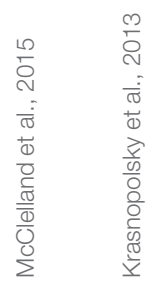

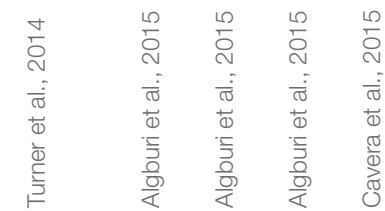

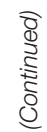

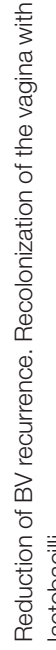
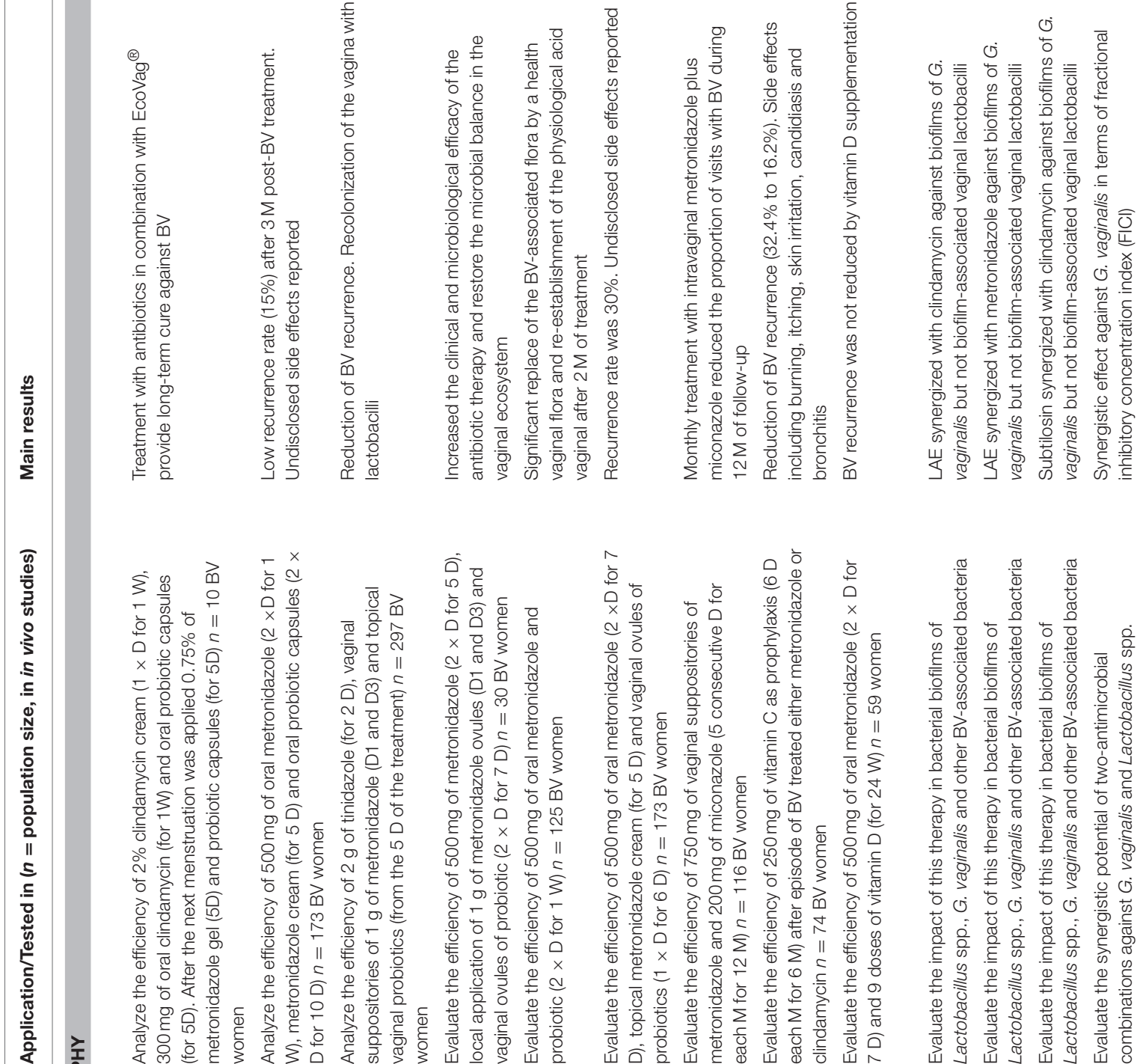

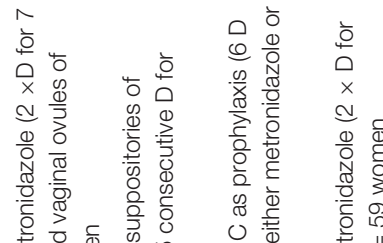
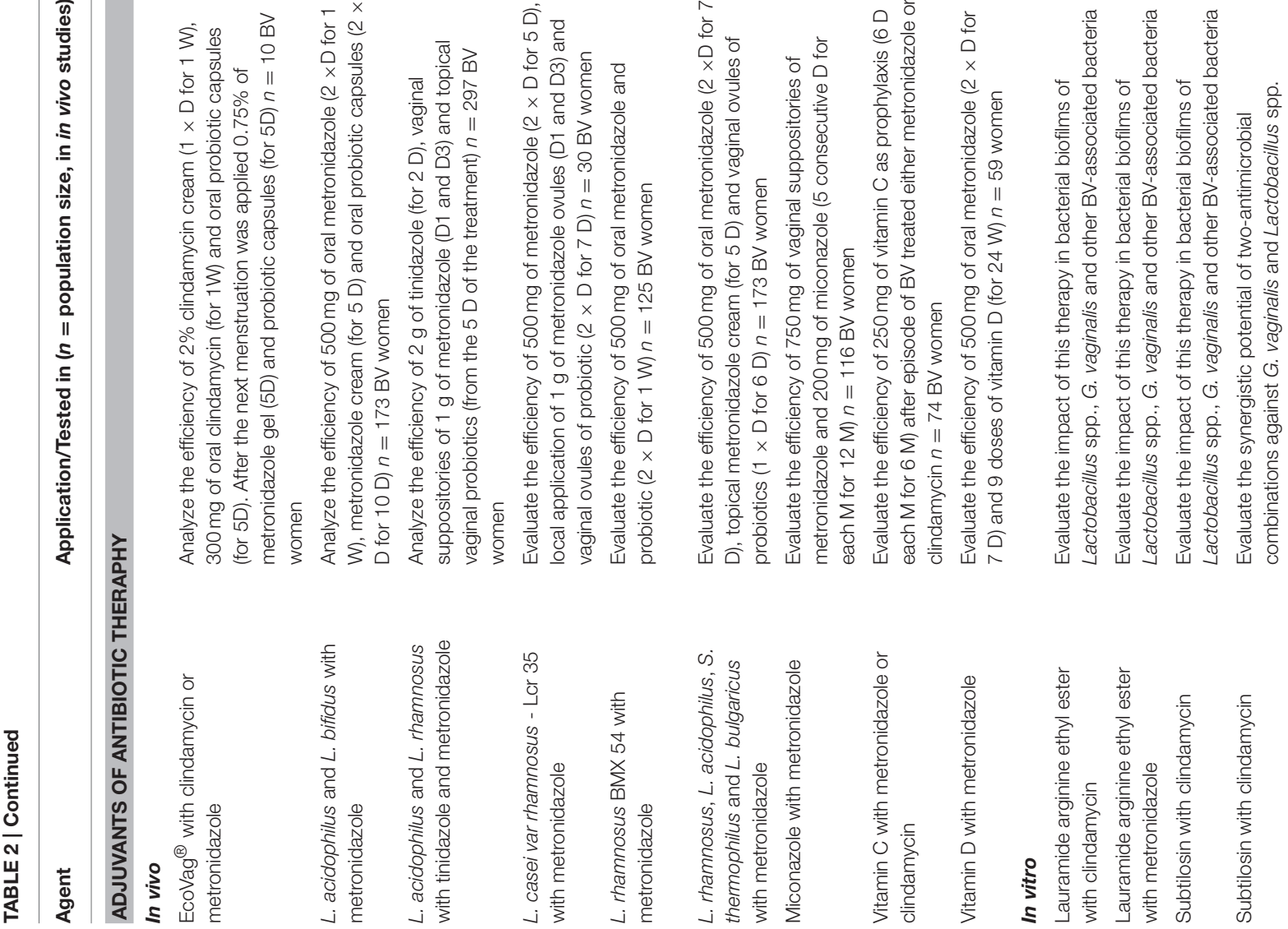


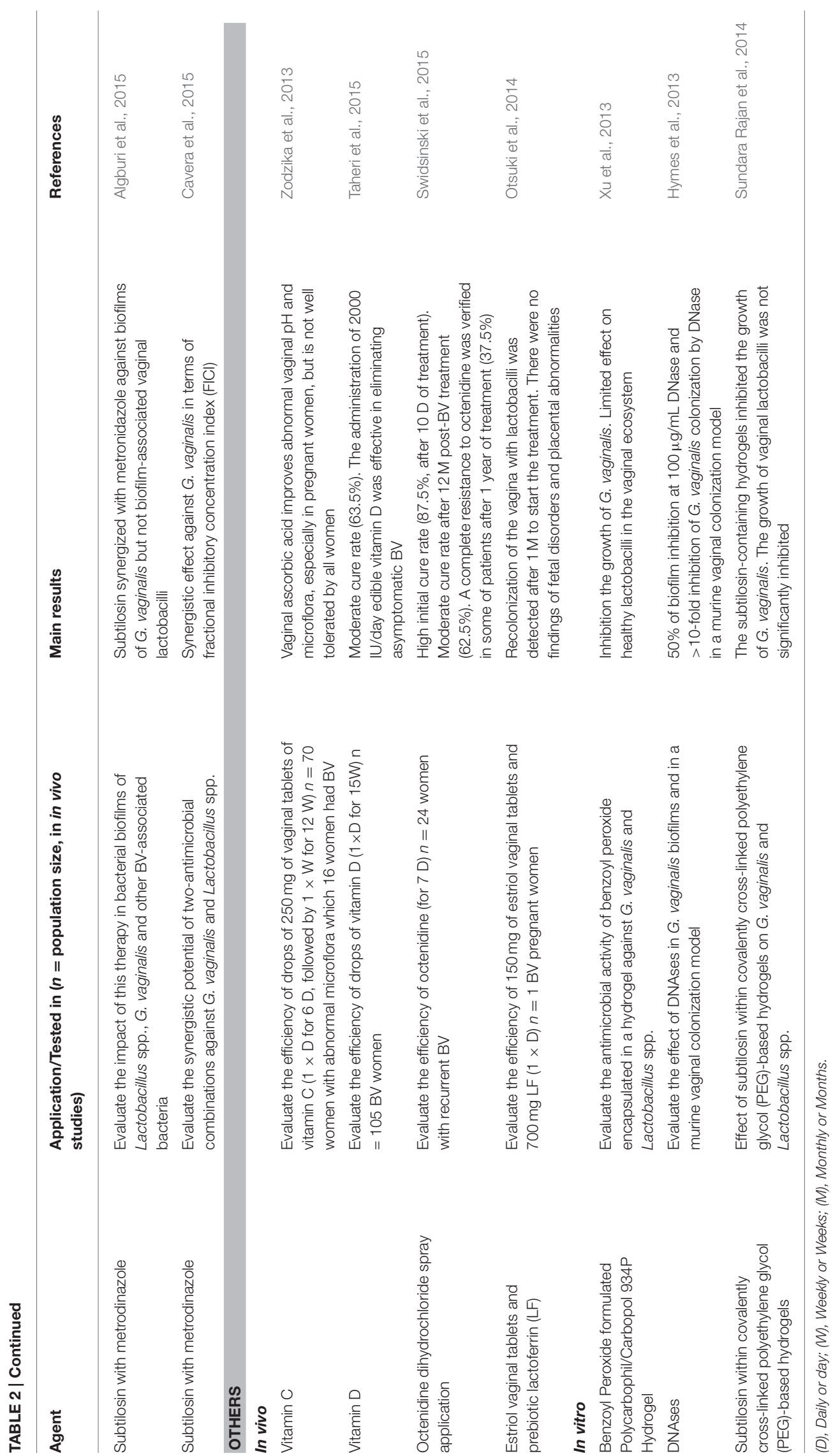


cream containing Zataria multiflora (Abdali et al., 2015), a vaginal douche of thymol and eugenol (main constituents of thyme oil and clove oil; Sosto et al., 2011), watery extract of Triticum vulgare (Boselli et al., 2012) and garlic tablets (Mohammadzadeh et al., 2014). Surprisingly, up to now only one study evaluated the capability of plant-derived compound to eradicate BV biofilms. Interestingly, Braga and colleagues showed that thymol, a molecule present in thyme essential oil, had an inhibitory effect upon both newly formed and mature G. vaginalis biofilms, which supports the importance of exploring essential oils and their main constituents as therapeutic alternative to treat BV (Braga et al., 2010). Furthermore, the expectations on essential oils as effective agents against BV-biofilms can be inferred from studies in other related vaginal biofilms (Palmeirade-Oliveira et al., 2012; Bogavac et al., 2015).

\section{Natural Antimicrobials}

Natural antimicrobials, mainly bacteriocins, have also been studied as potential therapeutic alternatives against BV. Several natural antimicrobials, including $L$. acidophilus 160 bacteriocin (Aroutcheva et al., 2001a), subtilosin (Sutyak et al., 2008, 2012; Cavera et al., 2015), lactocin 160 (Turovskiy et al., 2009), lactosporin (Riazi et al., 2012), fermenticin HV6b (Kaur et al., 2013), polylysine (Sutyak et al., 2012; Cavera et al., 2015), lauramide arginine ethyl ester (LAE) (Cavera et al., 2015; Sutyak et al., 2012) and glycerol monolaurate (Strandberg et al., 2010; Sutyak et al., 2012), displayed an inhibitory effect against BV-associated bacteria grown planktonically, usually not affecting the lactobacillary flora. Due to this important advantage, natural antimicrobials have also been proposed as a valuable therapeutic alternative to eradicate BV-biofilms. Remarkably, Turovskiy and colleagues tested the susceptibility of G. vaginalis biofilms to several natural antimicrobials. Using a series of in vitro assays, these researchers demonstrated that LAE had the strongest bactericidal effect against G. vaginalis biofilms, proposing LAE as a potential natural agent to disrupt BVbiofilm (Turovskiy et al., 2012). Later, Algburi and colleagues showed that subtilosin and LAE showed synergistic effect with clindamycin and metronidazole, inhibiting G. vaginalis biofilms, while not disturbing vaginal lactobacilli (Algburi et al., 2015). This demonstrated that the combination of conventional antibiotics with natural antimicrobials can improve the cure rates of antibiotic therapy, especially in cases where antimicrobial resistant was found.

\section{Acidifying/Buffering Agents}

Another interesting approach to treat BV is vaginal acidification (Boskey et al., 1999). However, the results concerning this strategy are controversial since acidification strategies alone, using acetic acid (Holley et al., 2004) or acid-buffering formulation (Simoes et al., 2006) showed to be somewhat ineffective against BV. Recently, Bahamondes and colleagues verified that a soap containing lactic acid and lactoserum could be used for external intimate hygiene, reducing BV recurrence after treatment with oral metronidazole (Bahamondes et al., 2011). Interestingly, vitamin $\mathrm{C}$, when coated with silicon, allowed the constant release of the active agent, resulting in a long-lasting vaginal low $\mathrm{pH}$ and prevention of vaginal irritation (Polatti et al., 2006). Other studies reported an effective and safe use of vaginal vitamin $\mathrm{C}$ tablets in BV treatment (Petersen et al., 2011), contributing to improve abnormal vaginal $\mathrm{pH}$ and microflora, especially in pregnant women (Zodzika et al., 2013). Additionally, the regular use of vitamin $C$ during 6 days per month, for 6 months after successful BV treatment, was shown to decrease the risk of BV recurrence (Krasnopolsky et al., 2013). Another alternative comes in the form of buffering agents. Polycarbophil is a weak poly-acid that it is able to adhere to vaginal epithelial cells, acting as a buffer in the vaginal secretions (Milani et al., 2000). Recently, a new benzoyl peroxide formulated polycarbophil/carbopol 934P hydrogel was shown to inhibit the growth of $G$. vaginalis with little or no effect on Lactobacillus spp. (Xu et al., 2013). Another agent that has been long used in the treatment of vaginal infections is boric acid (Van Slyke et al., 1981). Recently, Reichman and colleagues reported that the use of boric acid in combination with a nitroimidazole reduce the BV recurrence (Reichman et al., 2009), suggesting a potential impact on BV biofilms. However, this need to be further studied and in vitro biofilm experiments will elucidate the role of boric acid in $\mathrm{BV}$ prevention.

\section{Other Anti-Biofilm Agents}

An innovative approach to disrupt BV biofilms consists in the use of DNase which targets extracellular DNA. According to Hymes and colleagues, G. vaginalis biofilms contain extracellular DNA, which is essential to their structural integrity. In a series of in vitro studies, they showed that enzymatic disruption of extracellular DNA not only inhibited the formation of new biofilms but also destroyed the already formed ones (Hymes et al., 2013). In addition, DNase liberates bacteria from biofilms into the supernatant fractions and so potentiates the effect of metronidazole. Furthermore, using a murine model of vaginal colonization of $G$. vaginalis, these researchers also demonstrated that DNase treatment decreases the colonization density of $G$. vaginalis. Thus, DNase seems to be a promising therapeutic agent for BV either alone or in combination with antibiotics.

Another strategy involves the use of retrocyclin 101, a synthetic cyclic antimicrobial peptide with antiviral activity (Cole et al., 2007). Retrocyclin 101 and has been shown to inhibit the cytolytic activity of vaginolysin, a toxin produced by G. vaginalis, and to prevent de novo biofilm formation of this bacterial species (Hooven et al., 2012) while being well-tolerated by host tissues and by commensal vaginal bacteria (Eade et al., 2013).

\section{CONCLUSIONS AND FUTURE DIRECTIONS}

BV current approved therapies are not sufficient to deal with this multi-species biofilm-related vaginal disorder. Future, research should address biofilm communities with a particular emphasis on multi-species biofilms, a topic that only recently emerged (Castro and Cerca, 2015). By properly addressing the complex interactions established in multi-species biofilms, novel strategies will hopefully overcome the high recurrence and relapse rates associated with BV. 


\section{AUTHOR CONTRIBUTIONS}

DM prepared the first draft of the manuscript. JC prepared the first draft of the tables. NC, AO, and JO defined the content of the manuscript. All authors critically reviewed and approved the final version of the article.

\section{REFERENCES}

Abdali, K., Jahed, L., Amooee, S., Zarshenas, M., Tabatabaee, H., and Bekhradi, R. (2015). Comparison of the effect of vaginal Zataria multiflora cream and oral metronidazole pill on results of treatments for vaginal infections including trichomoniasis and bacterial vaginosis in women of reproductive age. Biomed. Res. Int. 2015:683640. doi: 10.1155/2015/683640

Aguin, T., Akins, R. A., and Sobel, J. D. (2014). High-dose vaginal maintenance metronidazole for recurrent bacterial vaginosis: a pilot study. Sex. Transm. Dis. 41, 290-291. doi: 10.1097/OLQ.0000000000000123

Algburi, A., Volski, A., and Chikindas, M. L. (2015). Natural antimicrobials subtilosin and lauramide arginine ethyl ester synergize with conventional antibiotics clindamycin and metronidazole against biofilms of Gardnerella vaginalis but not against biofilms of healthy vaginal lactobacilli. Pathog. Dis. 73:ftv018. doi: 10.1093/femspd/ftv018

Alves, P., Castro, J., Sousa, C., Cereija, T. B., and Cerca, N. (2014). Gardnerella vaginalis outcompetes 29 other bacterial species isolated from patients with bacterial vaginosis, using in an in vitro biofilm formation model. J. Infect. Dis. 210, 593-596. doi: 10.1093/infdis/jiu131

Aroutcheva, A. A., Simoes, J. A., and Faro, S. (2001a). Antimicrobial protein produced by vaginal Lactobacillus acidophilus that inhibits Gardnerella vaginalis. Infect. Dis. Obstet. Gynecol. 9, 33-39. doi: 10.1155/S1064744901000060

Aroutcheva, A., Gariti, D., Simon, M., Shott, S., Faro, J., Simoes, J. A., et al. (2001b). Defense factors of vaginal lactobacilli. Am. J. Obstet. Gynecol. 185, 375-379. doi: 10.1067/mob.2001.115867

Bahamondes, M. V., Portugal, P. M., Brolazo, E. M., Simões, J. A., and Bahamondes, L. (2011). Use of a lactic acid plus lactoserum intimate liquid soap for external hygiene in the prevention of bacterial vaginosis recurrence after metronidazole oral treatment. Rev. Assoc. Med. Bras. 57, 415-420. doi: 10.1590/S0104-42302011000400015

Beigi, R. H., Austin, M. N., Meyn, L. A., Krohn, M. A., and Hillier, S. L. (2004). Antimicrobial resistance associated with the treatment of bacterial vaginosis. Am. J. Obstet. Gynecol. 191, 1124-1129. doi: 10.1016/j.ajog.2004.05.033

Blackwell, A. L. (1991). Tea tree oil and anaerobic (bacterial) vaginosis. Lancet 337, 300. doi: 10.1016/0140-6736(91)90910-H

Bodean, O., Munteanu, O., Cirstoiu, C., Secara, D., and Cirstoiu, M. (2013). Probiotics-a helpful additional therapy for bacterial vaginosis. J. Med. Life 6, $434-436$.

Bogavac, M., Karaman, M., Janjuševiæ, L. J., Sudji, J., Radovanovi,æ, B., Novakoviæ, Z., et al. (2015). Alternative treatment of vaginal infections-in vitro antimicrobial and toxic effects of Coriandrum sativum L. and Thymus vulgaris L. essential oils. J. Appl. Microbiol. 119, 697-710. doi: 10.1111/jam.12883

Bohbot, J.-M., Vicaut, E., Fagnen, D., and Brauman, M. (2010). Treatment of bacterial vaginosis: a multicenter, double-blind, double-dummy, randomised phase III study comparing secnidazole and metronidazole. Infect. Dis. Obstet. Gynecol. 2010:705692. doi: 10.1155/2010/705692

Borges, S., Silva, J., and Teixeira, P. (2014). The role of lactobacilli and probiotics in maintaining vaginal health. Arch. Gynecol. Obstet. 289, 479-489. doi: 10.1007/s00404-013-3064-9

Boselli, F., Petrella, E., Campedelli, A., Muzi, M., Rullo, V., Ascione, L., et al. (2012). Efficacy and tolerability of fitostimoline (vaginal cream, ovules, and vaginal washing) and of benzydamine hydrochloride (tantum rosa vaginal cream and vaginal washing) in the topical treatment of symptoms of bacterial vaginosis. ISRN Obstet. Gynecol. 2012:183403. doi: 10.5402/2012/ 183403

\section{FUNDING}

Research on BV biofilms in NC laboratory is supported by funding from the Fundação para a Ciência e a Tecnologia (FCT) strategic project of unit UID/BIO/04469/2013. DM and JC acknowledge the FCT fellowships SFRH/BD/87569/2012 and SFRH/BD/93963/2013 respectively. NC is an Investigador FCT.

Boskey, E. R., Cone, R. A., Whaley, K. J., and Moench, T. R. (2001). Origins of vaginal acidity: high $\mathrm{D} / \mathrm{L}$ lactate ratio is consistent with bacteria being the primary source. Hum. Reprod. 16, 1809-1813. doi: 10.1093/humrep/16. 9.1809

Boskey, E. R., Telsch, K. M., Whaley, K. J., Moench, T. R., and Cone, R. A. (1999). Acid production by vaginal flora in vitro is consistent with the rate and extent of vaginal acidification. Infect. Immun. 67, 5170-5175.

Bradshaw, C. S., Morton, A. N., Hocking, J., Garland, S. M., Morris, M. B., Moss, L. M., et al. (2006). High recurrence rates of bacterial vaginosis over the course of 12 months after oral metronidazole therapy and factors associated with recurrence. J. Infect. Dis. 193, 1478-1486. doi: 10.1086/503780

Braga, P. C., Sasso, M. D., Culici, M., and Spallino, A. (2010). Inhibitory activity of thymol on native and mature Gardnerella vaginalis biofilms: in vitro study. Arzneimittelforschung 60, 675-681. doi: 10.1055/s-0031-1296346

Brotman, R. M., Klebanoff, M. A., Nansel, T. R., Yu, K. F., Andrews, W. W., Zhang, J., et al. (2010). Bacterial vaginosis assessed by Gram stain and diminished colonization resistance to incident gonococcal, chlamydial, and trichomonal genital infection. J. Infect. Dis. 202, 1907-1915. doi: 10.1086/657320

Cardone, A., Zarcone, R., Borrelli, A., Di-Cunzolo, A., Russo, A., and Tartaglia, E. (2003). Utilisation of hydrogen peroxide in the treatment of recurrent bacterial vaginosis. Minerva Ginecol. 55, 483-492.

Castro, J., and Cerca, N. (2015). BV and non-BV associated Gardnerella vaginalis establish similar synergistic interactions with other BV-associated microorganisms in dual-species biofilms. Anaerobe 36, 56-59. doi: 10.1016/j.anaerobe.2015.10.008

Cavera, V. L., Volski, A., and Chikindas, M. L. (2015). The natural antimicrobial subtilosin A synergizes with lauramide arginine ethyl ester (LAE), $\varepsilon$-polyl-lysine (polylysine), clindamycin phosphate and metronidazole, against the vaginal pathogen Gardnerella vaginalis. Probiotics Antimicrob. Proteins 7, 164-171. doi: 10.1007/s12602-014-9183-1

Centers for Disease Control and Prevention (2015). Sexually Transmitted Diseases Treatment Guidelines, 2015. Atlanta, GA: Center for Surveillance, Epidemiology, and Laboratory Services, Centers for Disease Control and Prevention (CDC), U.S. Department of Health and Human Services.

Cerca, N., Jefferson, K. K., Oliveira, R., Pier, G. B., and Azeredo, J. (2006). Comparative antibody-mediated phagocytosis of Staphylococcus epidermidis cells grown in a biofilm or in the planktonic state. Infect. Immun. 74, 4849-4855. doi: 10.1128/IAI.00230-06

Cerca, N., Martins, S., Cerca, F., Jefferson, K. K., Pier, G. B., Oliveira, R., et al. (2005). Comparative assessment of antibiotic susceptibility of coagulasenegative staphylococci in biofilm versus planktonic culture as assessed by bacterial enumeration or rapid XTT colorimetry. J. Antimicrob. Chemother. 56, 331-336. doi: 10.1093/jac/dki217

Chavoustie, S. E., Jacobs, M., Reisman, H. A., Waldbaum, A. S., Levy, S. F., Hillier, S. L., et al. (2015). Metronidazole vaginal gel $1.3 \%$ in the treatment of bacterial vaginosis?: a dose-ranging study. J. Low. Genit. Tract. Dis. 19, 129-134. doi: 10.1097/LGT.0000000000000062

Cole, A. L., Herasimtschuk, A., Gupta, P., Waring, A. J., Lehrer, R. I., and Cole, A. M. (2007). The retrocyclin analogue RC-101 prevents human immunodeficiency virus type 1 infection of a model human cervicovaginal tissue construct. Immunology 121, 140-145. doi: 10.1111/j.13652567.2006.02553.x

Coste, I., Judlin, P., Lepargneur, J. P., and Bou-Antoun, S. (2012). Safety and efficacy of an intravaginal prebiotic gel in the prevention of recurrent bacterial vaginosis: a randomized double-blind study. Obstet. Gynecol. Int. 2012:147867. doi: $10.1155 / 2012 / 147867$ 
Daniele, M., Pascual, L., and Barberis, L. (2014). Curative effect of the probiotic strain Lactobacillus fermentum L23 in a murine model of vaginal infection by Gardnerella vaginalis. Lett. Appl. Microbiol. 59, 93-98. doi: 10.1111/lam. 12249

Dickey, L. J., Nailor, M. D., and Sobel, J. D. (2009). Guidelines for the treatment of bacterial vaginosis: focus on tinidazole. Ther. Clin. Risk Manag. 5, 485-489. doi: 10.2147/TCRM.S3777

Donders, G. G. G., Guaschino, S., Peters, K., Tacchi, R., and Lauro, V. (2013). A multicenter, double-blind, randomized, placebo-controlled study of rifaximin for the treatment of bacterial vaginosis. Int. J. Gynecol. Obstet. 120, 131-136. doi: 10.1016/j.ijgo.2012.08.022

Eade, C. R., Cole, A. L., Diaz, C., Rohan, L. C., Parniak, M. A., Marx, P., et al. (2013). The anti-HIV microbicide candidate RC-101 inhibits pathogenic vaginal bacteria without harming endogenous flora or mucosa. Am. J. Reprod. Immunol. 69, 150-158. doi: 10.1111/aji.12036

Facchinetti, F., Dante, G., Pedretti, L., Resasco, P., Annessi, E., and Dodero, D. (2013). The role of oral probiotic for bacterial vaginosis in pregnant women. A pilot study. Minerva Ginecol. 65, 215-221.

Falagas, M., Betsi, G. I., and Athanasiou, S. (2007). Probiotics for the treatment of women with bacterial vaginosis. Clin. Microbiol. Infect. 13, 657-664. doi: 10.1111/j.1469-0691.2007.01688.x

Gallo, M. F., Macaluso, M., Warner, L., Fleenor, M. E., Hook, E. W., Brill, I., et al. (2012). Bacterial vaginosis, gonorrhea, and chlamydial infection among women attending a sexually transmitted disease clinic: a longitudinal analysis of possible causal links. Ann. Epidemiol. 22, 213-220. doi: 10.1016/j.annepidem.2011.11.005

Gardner, H. L., and Dukes, C. D. (1955). Haemophilus vaginalis vaginitis: a newly defined specific infection previously classified non-specific vaginitis. Am. J. Obstet. Gynecol. 69, 962-976.

Gerli, S., Rossetti, D., and Di-Renzo, G. C. (2003). A new approach for the treatment of bacterial vaginosis: use of polyhexamethylene biguanide. A prospective, randomized study. Eur. Rev. Med. Pharmacol. Sci. 7, 127-130.

Guerra, B., Ghi, T., Quarta, S., Morselli-labate, A. M., Lazzarotto, T., Pilu, G., et al. (2006). Pregnancy outcome after early detection of bacterial vaginosis. Eur. J. Obstet. Gynecol. Reprod. Biol. 128, 40-45. doi: 10.1016/j.ejogrb.2005.12.024

Ha, Y. M., Choi, J. S., Lee, B. B., Moon, H. E., Cho, K. K., and Choi, I. S. (2014). Inhibitory effects of seaweed extracts on the growth of the vaginal bacterium Gardnerella vaginalis. J. Environ. Biol. 35, 537-542.

Hantoushzadeh, S., Golshahi, F., Javadian, P., Khazardoost, S., Aram, S., Hashemi, S., et al. (2012). Comparative efficacy of probiotic yoghurt and clindamycin in treatment of bacterial vaginosis in pregnant women: a randomized clinical trial. J. Matern. Neonatal. Med. 25, 1021-1024. doi: 10.3109/14767058.2011.614654

Høiby, N., Ciofu, O., Johansen, H. K., Song, Z. J., Moser, C., Jensen, P. Ø., et al. (2011). The clinical impact of bacterial biofilms. Int. J. Oral Sci. 3, 55-65. doi: 10.4248/IJOS11026

Holley, R. L., Richter, H. E., Varner, R. E., Pair, L., and Schwebke, J. R. (2004). A randomized, double-blind clinical trial of vaginal acidification versus placebo for the treatment of symptomatic bacterial vaginosis. Sex. Transm. Dis. 31, 236-238. doi: 10.1097/01.OLQ.0000118423.20985.E7

Hooven, T. A., Randis, T. M., Hymes, S. R., Rampersaud, R., and Ratner, A. J. (2012). Retrocyclin inhibits Gardnerella vaginalis biofilm formation and toxin activity. J. Antimicrob. Chemother. 67, 2870-2872. doi: 10.1093/jac/dks305

Hymes, S. R., Randis, T. M., Sun, T. Y., and Ratner, A. J. (2013). DNase inhibits Gardnerella vaginalis biofilms in vitro and in vivo. J. Infect. Dis. 207, 1491-1497. doi: 10.1093/infdis/jit047

Ison, C. A., Taylor, R. F., Link, C., Buckett, P., Harris, J. R., and Easmon, C. S. (1987). Local treatment for bacterial vaginosis. Br. Med. J. 295:886. doi: 10.1136/bmj.295.6603.886

Jacobsson, B., Pernevi, P., Chidekel, L., and Platz-Christensen, J. J. (2002). Bacterial vaginosis in early pregnancy may predispose for preterm birth and postpartum endometritis. Acta Obstet. Gynecol. Scand. 81, 1006-1010. doi: 10.1034/j.16000412.2002.811103.x

Josey, W. E., and Schwebke, J. R. (2008). The polymicrobial hypothesis of bacterial vaginosis causation: a reassessment. Int. J. STD AIDS 19, 152-154. doi: 10.1258/ijsa.2007.007260

Kaewnopparat, S., Dangmanee, N., Kaewnopparat, N., Srichana, T., Chulasiri, M., and Settharaksa, S. (2013). In vitro probiotic properties of Lactobacillus fermentum SK5 isolated from vagina of a healthy woman. Anaerobe 22, 6-13. doi: 10.1016/j.anaerobe.2013.04.009

Kaur, B., Balgir, P. P., Mittu, B., Kumar, B., and Garg, N. (2013). Biomedical applications of fermenticin HV6b isolated from Lactobacillus fermentum HV6b MTCC10770. Biomed Res. Int. 2013:168438. doi: 10.1155/2013/168438

Koumans, E. H., Sternberg, M., Bruce, C., McQuillan, G., Kendrick, J., Sutton, M., et al. (2007). The prevalence of bacterial vaginosis in the United States, 20012004; associations with symptoms, sexual behaviors, and reproductive health. Sex. Transm. Dis. 34, 864-869. doi: 10.1097/OLQ.0b013e318074e565

Kovachev, S., and Dobrevski-Vacheva, R. (2013). Effect of Lactobacillus casei var rhamnosus (Gynophilus) in restoring the vaginal flora by female patients with bacterial vaginosis-randomized, open clinical trial. Akush. Ginekol. (Sofiia). 1, 48-53.

Kovachev, S., and Vatcheva-Dobrevski, R. (2013). Efficacy of combined 5nitroimidazole and probiotic therapy of bacterial vaginosis: randomized open trial. Akush. Ginekol. (Sofiia). 52, 19-26.

Krasnopolsky, V. N., Prilepskaya, V. N., Polatti, F., Zarochentseva, N. V., Bayramovab, G. R., Caserinid, M., et al. (2013). Efficacy of vitamin C vaginal tablets as prophylaxis for recurrent bacterial vaginosis?: a randomised. J. Clin. Med. Res. 5, 309-315. doi: 10.4021/jocmr1489w

Lachapelle, J., Castel, O., Casado, A. F., Leroy, B., Micali, G., Tennstedt, D., et al. (2013). Antiseptics in the era of bacterial resistance?: a focus on povidone iodine. Clin. Pract. 10, 579-592. doi: 10.2217/cpr.13.50

Leite, S. R. R. F., Amorim, M. M. R., Sereno, P. F. B., Leite, T. N. F., Ferreira, J. A. C., and Ximenes, R. A. A. (2011). Randomized clinical trial comparing the efficacy of the vaginal use of metronidazole with a Brazilian pepper tree (Schinus) extract for the treatment of bacterial vaginosis. Braz. J. Med. Biol. Res. 44, 245-252. doi: 10.1590/S0100-879X2011007500003

Leitich, H., Bodner-Adler, B., Brunbauer, M., Kaider, A., Egarter, C., and Husslein, P. (2003). Bacterial vaginosis as a risk factor for preterm delivery: a metaanalysis. Am. J. Obstet. Gynecol. 189, 139-147. doi: 10.1067/mob.2003.339

Ling, Z., Liu, X., Chen, W., Luo, Y., Yuan, L., Xia, Y., et al. (2013). The restoration of the vaginal microbiota after treatment for bacterial vaginosis with metronidazole or probiotics. Microb. Ecol. 65, 773-780. doi: 10.1007/s00248012-0154-3

Machado, A., and Cerca, N. (2015). The influence of biofilm formation by Gardnerella vaginalis and other anaerobes on bacterial vaginosis. J. Infect. Dis. doi: 10.1093/infdis/jiv338

Machado, A., Salgueiro, D., Harwich, M., Jefferson, K. K., and Cerca, N. (2013). Quantitative analysis of initial adhesion of bacterial vaginosis-associated anaerobes to ME-180 cells. Anaerobe 23, 1-4. doi: 10.1016/j.anaerobe.2013.07.007

Marcone, V., Rocca, G., Lichtner, M., and Calzolari, E. (2010). Long-term vaginal administration of Lactobacillus rhamnosus as a complementary approach to management of bacterial vaginosis. Int. J. Gynaecol. Obstet. 110, 223-226. doi: 10.1016/j.ijgo.2010.04.025

Marrazzo, J. M., Koutsky, L. A., Eschenbach, D. A., Agnew, K., Stine, K., and Hillier, S. L. (2002). Characterization of vaginal flora and bacterial vaginosis in women who have sex with women. J. Infect. Dis. 185, 1307-1313. doi: 10.1086/339884

Mastromarino, P., Brigidi, P., Macchia, S., Maggi, L., Pirovano, F., Trinchieri, V., et al. (2002). Characterization and selection of vaginal Lactobacillus strains for the preparation of vaginal tablets. J. Appl. Microbiol. 93, 884-893. doi: 10.1046/j.1365-2672.2002.01759.x

McClelland, R. S., Balkus, J. E., Lee, J., Anzala, O., Kimani, J., Schwebke, J., et al. (2015). Randomized trial of periodic presumptive treatment with high-dose intravaginal metronidazole and miconazole to prevent vaginal infections in HIV-negative women. J. Infect. Dis. 211, 1875-1882. doi: 10.1093/infdis/jiu818

McMillan, A., Dell, M., Zellar, M. P., Cribby, S., Martz, S., Hong, E., et al. (2011). Disruption of urogenital biofilms by lactobacilli. Colloids Surf. B Biointerfaces 86, 58-64. doi: 10.1016/j.colsurfb.2011.03.016

Menard, J. P. (2011). Antibacterial treatment of bacterial vaginosis: current and emerging therapies. Int. J. Womens Health 3, 295-305. doi: 10.2147/IJWH.S23814

Milani, M., Molteni, B., and Silvani, I. (2000). Effect on vaginal pH of a polycarbophil vaginal gel compared with an acidific douche in women with suspected bacterial vaginosis: a randomized, controlled study. Curr. Ther. Res. 61, 781-788. doi: 10.1016/S0011-393X(00)90004-3 
Moffett, M., and Mcgill, M. I. (1960). Treatment of trichomoniasis with metronidazole. Br. Med. J. 24, 910-911. doi: 10.1136/bmj.2.5203.910

Mohammadzadeh, F., Dolatian, M., Jorjani, M., Alavi Majd, H., and Borumandnia, N. (2014). Comparing the therapeutic effects of garlic tablet and oral metronidazole on bacterial vaginosis: a randomized controlled clinical trial. Iran. Red. Crescent. Med. J. 16:e19118. doi: 10.5812/ircmj.19118

Molteni, B., D’Antuono, A., Bandini, P., Sintini, G., Barcellona, E., Agnello, A., et al. (2004). Efficacy and tolerability of a new chlorhexidine-based vaginal gel in vaginal infections. Curr. Med. Res. Opin. 20, 849-853. doi: 10.1185/030079904125003692

Naidoo, D., van Vuuren, S. F., van Zyl, R. L., and de Wet, H. (2013). Plants traditionally used individually and in combination to treat sexually transmitted infections in northern Maputaland, South Africa: antimicrobial activity and cytotoxicity. J. Ethnopharmacol. 149, 656-667. doi: 10.1016/j.jep.2013.07.018

Nikolov, A., Shopova, E., Nashar, S., and Dimitrov, A. (2008). Application of sumamed in treatment of bacterial vaginal infections during pregnancy. Akush. Ginekol. (Sofiia). 47, 7-10.

Novakov Mikic, A., and Budakov, D. (2010). Comparison of local metronidazole and a local antiseptic in the treatment of bacterial vaginosis. Arch. Gynecol. Obstet. 282, 43-47. doi: 10.1007/s00404-009-1241-7

Núñez, J. T., and Gómez, G. (2005). Low-dose secnidazole in the treatment of bacterial vaginosis. Int. J. Gynaecol. Obstet. 88, 281-285. doi: 10.1016/j.ijgo.2004.11.028

Otsuki, K., Tokunaka, M., Oba, T., Nakamura, M., Shirato, N., and Okai, T. (2014). Administration of oral and vaginal prebiotic lactoferrin for a woman with a refractory vaginitis recurring preterm delivery: appearance of Lactobacillus in vaginal flora followed by term delivery. J. Obstet. Gynaecol. Res. 40, 583-585. doi: $10.1111 /$ jog. 12171

Paavonen, J., Mangioni, C., Martin, M. A., and Wajszczuk, C. P. (2000). Vaginal clindamycin and oral metronidazole for bacterial vaginosis: a randomized trial. Obstet. Gynecol. 96, 256-260. doi: 10.1016/S0029-7844(00)00902-9

Palmeira-de-Oliveira, A., Gaspar, C., Palmeira-de-Oliveira, R., Silva-Dias, A., Salgueiro, L., Cavaleiro, C., et al. (2012). The anti-Candida activity of Thymbra capitata essential oil: effect upon pre-formed biofilm. J. Ethnopharmacol. 140, 379-383. doi: 10.1016/j.jep.2012.01.029

Palmeira-de-Oliveira, A., Silva, B. M., Palmeira-de-Oliveira, R., Martinez-deOliveira, J., and Salgueiro, L. (2013). Are Plant Extracts a Potential Therapeutic Approach for Genital Infections? Curr. Med. Chem. 20, 2914-2928. doi: 10.2174/09298673113209990007

Patel, Y., Gopalan, S., Bagga, R., Sharma, M., Chopra, S., and Sethi, S. (2008). A randomized trial comparing a polyherbal pessary (a complementary and alternative medicine) with Ginlac-V pessary (containing clotrimazole, tinidazole and lactobacilli) for treatment of women with symptomatic vaginal discharge. Arch. Gynecol. Obstet. 278, 341-347. doi: 10.1007/s00404-008-0568-9

Patterson, J. L., Girerd, P. H., Karjane, N. W., and Jefferson, K. K. (2007). Effect of biofilm phenotype on resistance of Gardnerella vaginalis to hydrogen peroxide and lactic acid. Am. J. Obstet. Gynecol. 197, e1-e7. doi: 10.1016/j.ajog.2007.02.027

Pendharkar, S., Brandsborg, E., Hammarström, L., Marcotte, H., and Larsson, P. G. (2015). Vaginal colonisation by probiotic lactobacilli and clinical outcome in women conventionally treated for bacterial vaginosis and yeast infection. BMC Infect. Dis. 15, 255. doi: 10.1186/s12879-015-0971-3

Petersen, E. E., Genet, M., Caserini, M., and Palmieri, R. (2011). Efficacy of vitamin $\mathrm{C}$ vaginal tablets in the treatment of bacterial vaginosis: a randomised, double blind, placebo controlled clinical trial. Arzneimittelforschung 61, 260-265. doi: 10.1055/s-0031-1296197

Petersen, E. E., Weissenbacher, E. R., Hengst, P., Spitzbart, H., Weise, W. W., Wolff, F., et al. (2002). Local treatment of vaginal infections of varying etiology with dequalinium chloride or povidone iodine. A randomised, doubleblind, active-controlled, multicentric clinical study. Arzneimittelforschung 52, 706-715. doi: 10.1055/s-0031-1299955

Pirotta, M., Fethers, K. A., and Bradshaw, C. S. (2009). Bacterial vaginosis more questions than answers. Aust. Fam. Phys. 38, 394-397.

Polatti, F., Rampino, M., Magnani, P., and Mascarucci, P. (2006). Vaginal pHlowering effect of locally applied vitamin $\mathrm{C}$ in subjects with high vaginal $\mathrm{pH}$. Gynecol. Endocrinol. 22, 230-234. doi: 10.1080/09513590600647441

Ratzan, J. J. (1969). Monilial and trichomonal vaginitis. Topical treatment with povidone-iodine preparations. Calif. Med. 110, 24-27.
Ravel, J., Gajer, P., Abdo, Z., Schneider, G. M., Koenig, S. S. K., McCulle, S. L., et al. (2011). Vaginal microbiome of reproductive-age women. Proc. Natl. Acad. Sci. U.S.A. 108, 4680-4687. doi: 10.1073/pnas.1002611107

Recine, N., Palma, E., Domenici, L., Giorgini, M., Imperiale, L., Sassu, C., et al. (2016). Restoring vaginal microbiota: biological control of bacterial vaginosis. A prospective case-control study using Lactobacillus rhamnosus BMX 54 as adjuvant treatment against bacterial vaginosis. Arch. Gynecol. Obstet. 293 101-107. doi: 10.1007/s00404-015-3810-2

Reichman, O., Akins, R., and Sobel, J. D. (2009). Boric acid addition to suppressive antimicrobial therapy for recurrent bacterial vaginosis. Sex Transm. Dis. 36, 732-734. doi: 10.1097/OLQ.0b013e3181b08456

Riazi, S., Dover, S. E., and Chikindas, M. L. (2012). Mode of action and safety of lactosporin, a novel antimicrobial protein produced by Bacillus coagulans ATCC 7050. J. Appl. Microbiol. 113, 714-722. doi: 10.1111/j.13652672.2012.05376.x

Roberfroid, M. (2007). Prebiotics: the concept revisited. J. Nutr. 137, 830S-837S.

Rosen, A. D., and Rosen, T. (1999). Study of condom integrity after brief exposure to over-the-counter vaginal preparations. South. Med. J. 92, 305-307. doi: 10.1097/00007611-199903000-00009

Rossi, A., Rossi, T., Bertini, M., and Caccia, G. (2010). The use of Lactobacillus rhamnosus in the therapy of bacterial vaginosis. Evaluation of clinical efficacy in a population of 40 women treated for 24 months. Arch. Gynecol. Obstet. 281, 1065-1069. doi: 10.1007/s00404-009-1287-6

Rothman, K. J., Funch, D. P., Alfredson, T., Brady, J., and Dreyer, N. A. (2003). Randomized field trial of vaginal douching, pelvic inflammatory disease and pregnancy. Epidemiology 14, 340-348. doi: 10.1097/01.EDE.0000059230.67557.D3

Rousseau, V., Lepargneur, J. P., Roques, C., Remaud-Simeon, M., and Paul, F. (2005). Prebiotic effects of oligosaccharides on selected vaginal lactobacilli and pathogenic microorganisms. Anaerobe 11, 145-153. doi: 10.1016/j.anaerobe.2004.12.002

Saunders, S., Bocking, A., Challis, J., and Reid, G. (2007). Effect of Lactobacillus challenge on Gardnerella vaginalis biofilms. Colloids Surf. B Biosurf. 55, 138-142. doi: 10.1016/j.colsurfb.2006.11.040

Schwebke, J. R., and Desmond, R. A. (2011). Tinidazole versus metronidazole for treatment of bacterial vaginosis. Am. J. Obstet. Gynecol. 204, 211e1-211e6. doi: 10.1016/j.ajog.2010.10.898

Schwebke, J. R., Marrazzo, J., Andrew, P., and Sobel, J. D. (2015). A phase 3, multicenter, randomized, double-blind, vehicle-controlled study evaluating the safety and efficacy of metronidazole vaginal gel $1.3 \%$ in the treatment of bacterial vaginosis. Sex Transm. Dis. 42, 376-381. doi: 10.1097/OLQ.0000000000000300

Schwebke, J. R., Muzny, C. A., and Josey, W. E. (2014). Role of Gardnerella vaginalis in the pathogenesis of bacterial vaginosis: a conceptual model. J. Infect. Dis. 210, 338-343. doi: 10.1093/infdis/jiu089

Shaaban, O. M., Fetih, G. N., Abdellah, N. H., Ismail, S., Ibrahim, M. A., and Ibrahim, E. A. (2011). Pilot randomized trial for treatment of bacterial vaginosis using in situ forming metronidazole vaginal gel. J. Obstet. Gynaecol. Res. 37, 874-881. doi: 10.1111/j.1447-0756.2010.01457.x

Simoes, J. A., Bahamondes, L. G., Camargo, R. P. S., Alves, V. M. N., Zaneveld, L. J. D., Waller, D. P., et al. (2006). A pilot clinical trial comparing an acid-buffering formulation (ACIDFORM gel) with metronidazole gel for the treatment of symptomatic bacterial vaginosis. Br. J. Clin. Pharmacol. 61, 211-217. doi: 10.1111/j.1365-2125.2005.02550.x

Sobel, J. D. (2000). Bacterial vaginosis. Annu. Rev. Med. 51, 349-356. doi: 10.1146/annurev.med.51.1.349

Sosto, F., Benvenuti, C., and CANVA Study Group (2011). Controlled study on thymol + eugenol vaginal douche versus econazole in vaginal candidiasis and metronidazole in bacterial vaginosis. Arzneimittelforschung 61, 126-131. doi: 10.1055/s-0031-1296178

Strandberg, K. L., Peterson, M. L., Lin, Y.-C., Pack, M. C., Chase, D. J., and Schlievert, P. M. (2010). Glycerol monolaurate inhibits Candida and Gardnerella vaginalis in vitro and in vivo but not Lactobacillus. Antimicrob. Agents Chemother. 54, 597-601. doi: 10.1128/AAC.01151-09

Sundara Rajan, S., Cavera, V. L., Zhang, X., Singh, Y., Chikindas, M. L., and Sinko, P. J. (2014). Polyethylene glycol-based hydrogels for controlled release of the antimicrobial subtilosin for prophylaxis of bacterial vaginosis. Antimicrob. Agents Chemother. 58, 2747-2753. doi: 10.1128/AAC.02446-14 
Sutyak, K. E., Wirawan, R. E., Aroutcheva, A. A., and Chikindas, M. L. (2008). Isolation of the Bacillus subtilis antimicrobial peptide subtilosin from the dairy product-derived Bacillus amyloliquefaciens. J. Appl. Microbiol. 104, 1067-1074. doi: 10.1111/j.1365-2672.2007.03626.x

Sutyak, K. N., Prichard, M. N., Khaykin, A., Sinko, P. J., and Chikindas, M. L. (2012). The natural antimicrobial peptide subtilosin acts synergistically with glycerol monolaurate, lauric arginate, and -poly-l-lysine against bacterial vaginosis-associated pathogens but not human lactobacilli. Antimicrob. Agents Chemother. 56, 1756-1761. doi: 10.1128/AAC.05861-11

Swidsinski, A., Loening-Baucke, V., Swidsinski, S., and Verstraelen, H. (2015). Polymicrobial Gardnerella biofilm resists repeated intravaginal antiseptic treatment in a subset of women with bacterial vaginosis: a preliminary report. Arch. Gynecol. Obstet. 291, 605-609. doi: 10.1007/s00404-014-3484-1

Swidsinski, A., Mendling, W., Loening-Baucke, V., Ladhoff, A., Swidsinski, S., Hale, L. P., et al. (2005). Adherent biofilms in bacterial vaginosis. Obstet. Gynecol. 106, 1013-1023. doi: 10.1097/01.AOG.0000183594.45524.d2

Swidsinski, A., Mendling, W., Loening-Baucke, V., Swidsinski, S., Dörffel, Y., Scholze, J., et al. (2008). An adherent Gardnerella vaginalis biofilm persists on the vaginal epithelium after standard therapy with oral metronidazole. Am. J. Obstet. Gynecol. 198, 97.e1-e6. doi: 10.1016/j.ajog.2007.06.039

Taheri, M., Baheiraei, A., Foroushani, A. R., Nikmanesh, B., and Modarres, M. (2015). Treatment of vitamin D deficiency is an effective method in the elimination of asymptomatic bacterial vaginosis: a placebo-controlled randomized clinical trial. Indian J. Med. Res. 141, 799-806. doi: 10.4103/09715916.160707

Tally, F. P., Sutter, V. L., and Finegold, S. M. (1975). Treatment of anaerobic infections with metronidazole. Antimicrob. Agents Chemother. 7, 672-675. doi: 10.1128/AAC.7.5.672

Thulkar, J., Kriplani, A., and Agarwal, N. (2012). A comparative study of oral single dose of metronidazole, tinidazole, secnidazole and ornidazole in bacterial vaginosis. Indian J. Pharmacol. 44, 243-245. doi: 10.4103/0253-7613.93859

Tobudic, S., Kratzer, C., Lassnigg, A., and Presterl, E. (2012). Antifungal susceptibility of Candida albicans in biofilms. Mycoses 55, 199-204. doi: 10.1111/j.1439-0507.2011.02076.x

Togni, G., Battini, V., Bulgheroni, A., Mailland, F., Caserini, M., and Mendling, W. (2011). In vitro activity of nifuratel on vaginal bacteria: could it be a good candidate for the treatment of bacterial vaginosis? Antimicrob. Agents Chemother. 55, 2490-2492. doi: 10.1128/AAC.01623-10

Trexler, M. F., Fraser, T. G., and Jones, M. P. (1997). Fulminant pseudomembranous colitis caused by clindamycin phosphate vaginal cream. Am. J. Gastroenterol. 92, 2112-2113.

Turner, A. N., Carr Reese, P., Fields, K. S., Anderson, J., Ervin, M., Davis, J. A., et al. (2014). A blinded, randomized controlled trial of high-dose vitamin D supplementation to reduce recurrence of bacterial vaginosis. Am. J. Obstet. Gynecol. 211, 479.e1-e13. doi: 10.1016/j.ajog.2014.06.023

Turovskiy, Y., Cheryian, T., Algburi, A., Wirawan, R. E., Takhistov, P., Sinko, P. J., et al. (2012). Susceptibility of Gardnerella vaginalis biofilms to natural antimicrobials subtilosin, $\varepsilon$-poly-L-Lysine, and lauramide arginine ethyl ester. Infect. Dis. Obstet. Gynecol. 2012:284762. doi: 10.1155/2012/284762

Turovskiy, Y., Ludescher, R. D., Aroutcheva, A. A., Faro, S., and Chikindas, M. L. (2009). Lactocin 160, a bacteriocin produced by vaginal Lactobacillus rhamnosus, targets cytoplasmic membranes of the vaginal pathogen, Gardnerella vaginalis. Probiotics Antimicrob. Proteins 1, 67-74. doi: 10.1007/s12602-008-9003-6

Food and Agriculture Organization of the United Nations and World Health Organization (2001). Health and Nutritional Properties of Probiotics in Food Including Powder Milk with Live Lactic Acid Bacteria. Córdoba.
Van Slyke, K. K., Michel, V. P., and Rein, M. F. (1981). Treatment of vulvovaginal candidiasis with boric acid powder. Am. J. Obstet. Gynecol. 141, 145-148.

Verhelst, R., Verstraelen, H., Claeys, G., Verschraegen, G., Delanghe, J., Van Simaey, L., et al. (2004). Cloning of 16 S rRNA genes amplified from normal and disturbed vaginal microflora suggests a strong association between Atopobium vaginae, Gardnerella vaginalis and bacterial vaginosis. BMC Microbiol. 4:16. doi: 10.1186/1471-2180-4-16

Verstraelen, H., Verhelst, R., Roelens, K., and Temmerman, M. (2012). Antiseptics and disinfectants for the treatment of bacterial vaginosis: a systematic review. BMC Infect. Dis. 12:148. doi: 10.1186/1471-2334-12-148

Vicariotto, F., Mogna, L., and Del Piano, M. (2014). Effectiveness of the two microorganisms Lactobacillus fermentum LF15 and Lactobacillus plantarum LP01, formulated in slow-release vaginal tablets, in women affected by bacterial vaginosis A Pilot Study. J. Clin. Gastroenterol. 48, S106-S112. doi: 10.1097/MCG.0000000000000226

Vujic, G., Knez, A. J., Stefanovic, V. D., and Vrbanovic, V. K. (2013). Efficacy of orally applied probiotic capsules for bacterial vaginosis and other vaginal infections: a double-blind, randomized, placebo-controlled study. Eur. J. Obstet. Gynecol. Reprod. Biol. 168, 75-79. doi: 10.1016/j.ejogrb.2012. 12.031

Wewalka, G., Stary, A., Bosse, B., Duerr, H. E., and Reimer, K. (2002). Efficacy of povidone-iodine vaginal suppositories in the treatment of bacterial vaginosis. Dermatology 204, 79-85. doi: 10.1159/000057731

Wood, B. A., and Monro, A. M. (1975). Pharmacokinetics of tinidazole and metronidazole in women after single large oral doses. Br. J. Vener. Dis. 51, 51-53. doi: 10.1136/sti.51.1.51

Xie, Z., Thompson, A., Sobue, T., Kashleva, H., Xu, H., Vasilakos, J., et al. (2012). Candida albicans biofilms do not trigger reactive oxygen species and evade neutrophil killing. J. Infect. Dis. 206, 1936-1945. doi: 10.1093/infdis/jis607

Xu, S., Cavera, V. L., Rogers, M. A., Huang, Q., Zubovskiy, K., and Chikindas, M. L. (2013). Benzoyl peroxide formulated polycarbophil/carbopol 934P hydrogel with selective antimicrobial activity, potentially beneficial for treatment and prevention of bacterial vaginosis. Infect. Dis. Obstet. Gynecol. 2013:909354. doi: $10.1155 / 2013 / 909354$

Zeng, Z. M., Liao, Q. P., Yao, C., Geng, L., Feng, L. H., Shi, H. R., et al. (2010). Directed shift of vaginal flora after topical application of sucrose gel in a phase III clinical trial: a novel treatment for bacterial vaginosis. Chin. Med. J. (Engl.) 123, 2051-2057.

Zodzika, J., Rezeberga, D., Donders, G., Vedmedovska, N., Vasina, O., Pundure, I., et al. (2013). Impact of vaginal ascorbic acid on abnormal vaginal microflora. Arch. Gynecol. Obstet. 288, 1039-1044. doi: 10.1007/s00404-013-2876-y

Conflict of Interest Statement: The authors declare that the research was conducted in the absence of any commercial or financial relationships that could be construed as a potential conflict of interest.

LABFIT works in the development of plant-based therapheutics against vaginal infections; APO is co-president of Labfit.

Copyright (c) 2016 Machado, Castro, Palmeira-de-Oliveira, Martinez-de-Oliveira and Cerca. This is an open-access article distributed under the terms of the Creative Commons Attribution License (CC BY). The use, distribution or reproduction in other forums is permitted, provided the original author(s) or licensor are credited and that the original publication in this journal is cited, in accordance with accepted academic practice. No use, distribution or reproduction is permitted which does not comply with these terms. 